\title{
The Effect of Nickel Slag Concentrationas Coarse Aggregates on the Compressive Strength of Concrete
}

\author{
Rini Sriyani ${ }^{1}$, Edward Ngii ${ }^{2}$, Abdul Kadir ${ }^{3}$, Muh. Hasbi ${ }^{4}$, Uniadi Mangidi ${ }^{5}$, Dwi \\ Endang Wahyuni ${ }^{6}$ \\ \{rinisriyani.uho@gmail.com¹, edward.ngii@uho.ac.id², kadir12340@yahoo.com³, \\ uniadi05@yahoo.com ${ }^{4}$ \} \\ 1,2,3,4,5,6 Faculty of Engineering, Halu Oleo University, Bumi Hijau Campuss, \\ H.E.A. Mokodompit Street, Andonohu, Kendari, 93232, Indonesia
}

\begin{abstract}
Production of nickel slag waste from PT. Antam Pomalaa currently reaches 1 million tons/year. One effort to reduce the waste is by using it as an aggregate of concrete mixtures. However, the use of substandard agglomerates (nickel slags) to replace natural aggregates as a whole has not been possible. The purpose of this study was to determine the compressive strength of concrete that used nickel slag as coarse aggregate. Nickel slagswere broken down with a stone crusher and filtered into coarse aggregates with the size of 1-2 cm. Concrete mix design referred to SNI 03-2834-200. The nickel slag was varied by a concentration of $0 \%, 25 \%, 50 \%, 75 \%$, and $100 \%$. The specimens were a cube with the length, width, and height of $15 \times 15 \times 15 \mathrm{~cm}$ with a total of 15 cubes. Testing was done after the concrete reached the age of 28 days with a compression test tool. The test results show that the compressive strength of concrete at the age of 28 days for the samples with slag concentration of $0 \%$ (control), $25 \%, 50 \%, 75 \%$, and $100 \%$ reached 17.61 MPa, 13.65 MPa, 17.24 MPa, 17.34 MPa, and 21.95 MPa, respectively.
\end{abstract}

Keywords: Concrete, Nickel Slag, Aggregate, Cement, Compressive.

\section{Introduction}

Coarse aggregate is one of the concrete constituent materials. Coarse aggregate can be used as concrete material if it meets technical requirements. But in reality not all regions are able to provide natural rock sources that meet the requirements to be processed as coarse aggregates. This condition often occurs in islands or coastal areas as a result of which the cost of concrete construction in the area becomes very expensive because it must bring in rough aggregates from other regions. Therefore efforts to obtain coarse aggregate resources continue to be carried out to support sustainable development.

Previously nickel slag was used more as a material for shore or beach reclamation, but since the issuance of PP No. 101 of 2014 which states nickel slag as B3 category waste, then nickel slag becomes a hazardous material if left unchecked.

Efforts to utilize slag as a construction material have been carried out, for example nickel slag as a substitute for cement in high quality concrete [1] and as a substitute filler for asphalt mixture [2]. Both research results show that nickel slag can be used in asphalt and concrete mixtures. The use of nickel slag in cement-based construction will result in environmentally friendly construction because the heavy metals in the slag are more stable. This is based on research by [3] obtained $\mathrm{HgS}$ (Sulfur from cement + mercury) compounds and [4], which 
stabilized heavy metals with cement in concrete which formed new compounds $\mathrm{Ca}$ ( $\mathrm{Zn}$ $\left.(\mathrm{OH})_{3}\right)_{2} \cdot 2 \mathrm{H}_{2} \mathrm{O}$ (cement + zinc).

The use of nickel slag as coarse aggregate has been carried out by [5] who uses nickel slag (40 mm in diameter) with ingredients added with rice husk ash. The results showed an increase in slag concrete strength of $6.5 \%$ in the addition of $15 \%$ rice husk ash. Another study by [6] dan [7] which used nickel slag as a substitute for all coarse aggregates showed an increase in concrete compressive strength of normal slag concrete.

Although the use of nickel slag as aggregate can increase compressive strength but in its application, the use of nickel slag as a substitute for natural aggregate has not been recommended because there are no technical specifications for the use of nickel slag in concrete mixtures. In addition, the slag concrete produced has a unit weight higher than normal concrete and has the potential to pollute the environment. One effort to reduce the environmental impact and reduce the slag unit weight is to replace a portion of coarse aggregates.

\subsection{The aim of this research}

1) To determine the value of concrete compressive strength due to the use of slag variations.

2) To find out the composition of slag which produces maximum compressive strength by using slag nickel conventional as coarse aggregate

\section{Material and Method}

The material used in this study consisted of cement tonasa, standard aggregate (moramo stone), nickel slag aggregate obtained from PT. Antam Pomalaa, Kolaka Regency and broken down into split sizes 1-2 cm, using stonecrusher in Moramo area, pohara sand and water PDAM.

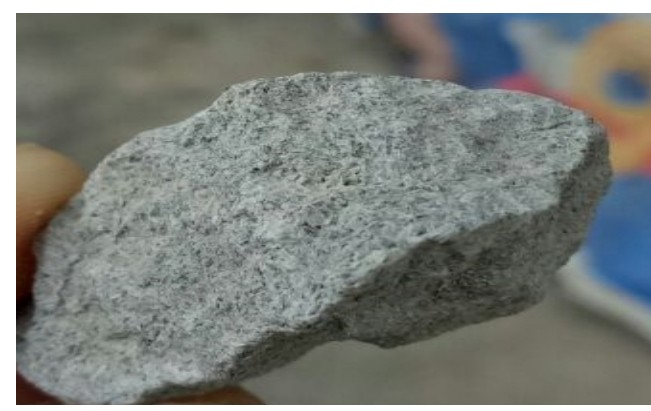

Fig. 1. Slag stone of fenil 2 from PT. Antam Pomalaa

Coarse and fine aggregate materials are examined according to the applicable SNI standards. Concrete design using concrete mixture planning method ratio weight 1: 2: 3 . The specimens were made in two groups, namely normal concrete (NC) and slag (SC) concrete in cubes with a length, width and height of each of $150 \times 150 \times 150 \mathrm{~mm}$. Each variation of the mixture is made of specimens 3 specimens with the composition as in Table 1. 
Table 1. Material composition of normal concrete and slag concrete.

\begin{tabular}{ccccccccc}
\hline \multirow{2}{*}{$\begin{array}{c}\text { Code of } \\
\text { samples }\end{array}$} & \multirow{2}{*}{ Description } & \multicolumn{3}{c}{ \% of Aggregate } & \multicolumn{5}{c}{ Compotition of concrete material $(\mathrm{kg} / \mathrm{m} 3)$} \\
\cline { 3 - 9 } & & Slag & Normal & Slag & Normal & Sand & Cement & Water \\
\hline NC & Normal Concrete & 0 & 100 & 0 & 1098 & 732 & 366 & 183 \\
SC.25 & Slag Concrete & 25 & 75 & 278 & 833 & 740 & 366 & 185 \\
SC.50 & Slag Concrete & 50 & 50 & 561 & 561 & 748 & 366 & 187 \\
SC.75 & Slag Concrete & 75 & 25 & 852 & 284 & 757 & 366 & 189 \\
SC.100 & Slag Concrete & 100 & 0 & 1148 & 0 & 766 & 366 & 191 \\
\hline
\end{tabular}

Compressive strength test was carried out using the crushing test method using a hydraulic press (compression test mechine) after the concrete was 28 days old. Characteristic concrete compressive strength $\left(\sigma_{b k}\right)$ is analyzed using equation (1) by calculating destructive stress $(1)$ by calculating destructive stress $\left(\sigma_{b i}\right)$, destructive stress mean $\left(\sigma_{b m}\right)$, and standard deviation $\left(S_{d}\right)$.

$$
\sigma_{b k}=\sigma_{b m}-1.64 S_{d}
$$

\section{Result and Discussion}

\subsection{Material Testing Results}

The coarse aggregate and fine aggregate test results used are presented in Table 2, as follows:

Table 2. Properties of coarse aggregate and fine aggregate

\begin{tabular}{|c|c|c|c|c|c|c|}
\hline \multirow[b]{2}{*}{ No. } & \multirow[b]{2}{*}{ Pemeriksaan } & \multicolumn{3}{|c|}{ Coarse Aggregate } & \multicolumn{2}{|c|}{ Fine Aggregate } \\
\hline & & Normal & Slag & $\begin{array}{c}\text { SNI } \\
\text { Specification }\end{array}$ & $\begin{array}{l}\text { Pohara } \\
\text { Sand }\end{array}$ & $\begin{array}{c}\text { SNI } \\
\text { Specification }\end{array}$ \\
\hline 1 & Berat jenis kering & 2.55 & 2.88 & $2,4-2,9$ & 2.61 & $2,4-2,9$ \\
\hline 2 & Berat jenis SSD & 2.59 & 2.90 & $2,4-2,9$ & 2.63 & $2,4-2,9$ \\
\hline 3 & Berat jenis semu & 2.64 & 2.95 & $2,4-2,9$ & 2.85 & $2,4-2,9$ \\
\hline 4 & Penyerapan (\%) & 1.31 & 0.88 & $<3 \%$ & 0.84 & $<3 \%$ \\
\hline 5 & Berat isi lepas $\left(\mathrm{gr} / \mathrm{cm}^{3}\right)$ & 1.36 & 1.52 & $1.4-1.9$ & 1.51 & $1.4-1.9$ \\
\hline 6 & Berat isi padat $\left(\mathrm{gr} / \mathrm{cm}^{3}\right)$ & 1.51 & 1.62 & $1.4-1.9$ & 1.63 & $1.4-1.9$ \\
\hline 7 & Kadar lumpur (\%) & 0.54 & 0.09 & $\leq 1 \%$ & 2.36 & $<5 \%$ \\
\hline 8 & Kadar air (\%) & 0.17 & 0.09 & $3-5 \%$ & 0.33 & $3-5 \%$ \\
\hline 9 & Modulus Halus Butir (\%) & 6.78 & 7.12 & $0-7$ & 3.03 & $2.5-3.8$ \\
\hline 10 & Keausan $(\%)$ & 31.53 & 40.92 & & - & - \\
\hline 11 & Aggregate Impact Value (\%) & 21.30 & 25.70 & $<30 \%$ & - & - \\
\hline
\end{tabular}

Based on the results of testing the specific gravity, coarse aggregates derived from nickel slag are included in heavy aggregates with specific gravity above 2.8. Aggregates of specific gravity between 2.5 to $2.7 \mathrm{gr} / \mathrm{cm}^{3}$ will produce a type of heavy concrete of around $2.3 \mathrm{gr} / \mathrm{cm}^{3}$ [8]. If the type of aggregate is high in weight, then the resulting concrete is of high density and has high compressive strength.

Nickel slag abrasion test results were $40.92 \%$ so that they could meet the aggregate requirements for class II concrete manufacturing $\left(100 \mathrm{~kg} / \mathrm{cm}^{2}-200 \mathrm{~kg} / \mathrm{cm}^{2}\right)$. The value of abrasion indicates resistance or coarse aggregate strength to wear. The aggregate strength has 
an effect on the strength of the concrete, the weak aggregate will not produce strong concrete and to make high quality strength concrete must be of high aggregate strength.

One measure of aggregate strength is the impact value. Impact test experiments were conducted to determine the aggregate strength of shock loads, so that the planned structure is safe against shock loads. the impact value of the moramo stone and nickel slag obtained were $21.30 \%$ and $25.70 \%$ respectively. According to SNI 03-4426-1997 the maximum aggregate strength requirement is $30 \%$. Based on existing standards, the imapct value for each of the aggregates of nickel and slag stones still qualifies as normal aggregates that can be used in construction.

\subsection{The Compressive Strength}

The results of the compressive strength test at the age of 28 days are shown in Table 3 below:

Table 1. Result of compressive strengthtest after 28 days curring.

\begin{tabular}{|c|c|c|c|c|c|}
\hline \multirow{2}{*}{$\begin{array}{l}\text { Number of } \\
\text { variation }\end{array}$} & \multirow{2}{*}{$\begin{array}{l}\text { Description (concrete } \\
\text { code) }\end{array}$} & \multirow{2}{*}{$\begin{array}{c}\text { Normal } \\
\text { agregat } \\
(\%)\end{array}$} & \multirow{2}{*}{$\begin{array}{c}\text { Slag } \\
\text { agregat } \\
(\%)\end{array}$} & \multicolumn{2}{|c|}{ Compressive Strength } \\
\hline & & & & $\left(\mathrm{Kg} / \mathrm{cm}^{2}\right)$ & $(\mathrm{MPa})$ \\
\hline Variasi 1 & Normal Concrete (NC) & 100 & 0 & 212.22 & 17.61 \\
\hline Variasi 2 & Slag Concrete (SC.25) & 75 & 25 & 164.44 & 13.65 \\
\hline Variasi 3 & Slag Concrete (SC.50) & 50 & 50 & 207.77 & 17.24 \\
\hline Variasi 4 & Slag Concrete (SC.75) & 25 & 75 & 208.88 & 17.34 \\
\hline Variasi 5 & Slag Concrete (SC.100) & 0 & 100 & 264.44 & 21.95 \\
\hline
\end{tabular}

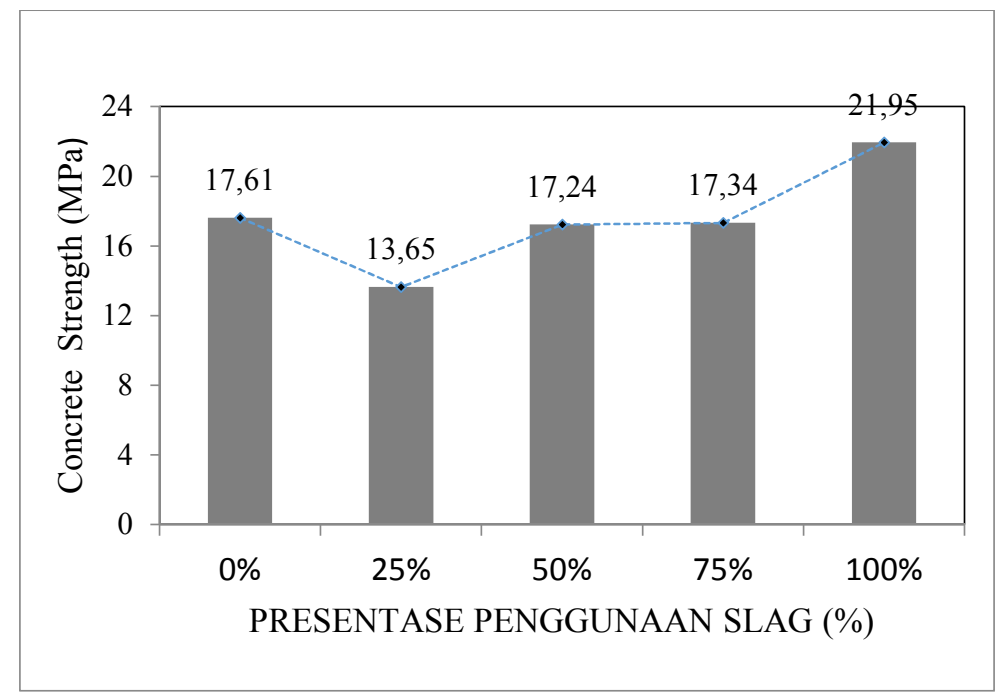

Fig. 1. Graph of slag concrete compressive strength based on variations in the use of slag in the mixture. 
Based on the graph above the compressive strength using Moramo $100 \%$ (V1) has a compressive strength of $17.61 \mathrm{MPa}$, while at (V2) slag use $25 \%$ has a compressive strength of 13.65 MPa. This shows a decrease in compressive strength of $22 \%$ from compressive strength V1. and at (V3) with the use of 50\% slag compressive strength decreased by $2 \%$ from the compressive strength of the test object (V1) that is equal to $17.24 \mathrm{MPa}$ and on the test object (V4) the use of $75 \%$ slag also decreased by 1.5 compressive strength $\%$ of the test object (V1) and has a compressive strength of $17.34 \mathrm{MPa}$. Whereas in the test object (V5) using $100 \%$ slag has the maximum compressive strength of the other specimens which is equal to 21.95 $\mathrm{MPa}$ and has a $24.6 \%$ increase in the test specimen (V1).

Theseresults indicate that the use of nickel to $100 \%$ slag in a concrete mixture will provide an advantage in increasing the strength of the concrete mixture. Although the abrasion value is lower, the use of broken nickel slag can increase the strength of the concrete mixture to $25 \%$ higher than using the normal aggregate of moramo stone.

\section{Conclusion}

The conclusions from the results of this study is that the use of nickel slag in concrete mixtures can affect the value of compressive strength of concrete, the more slag composition is used, the higher the value of compressive strength in concrete.

\section{References}

[1] Sugiri, Saptahari: Penggunaan terak nikel sebagai agregat dan campuran semen pada beton mutu tinggi. Jurnal Infrastruktur dan Lingkungan Binaan. I. (1), 1-8, 2005.

[2] Ngii, E. and Baso Mursidi: Nickel Slag as an Alternative Material to Substitute Stone Dust (Filler) On Road Construction, The 1st International Seminar on Sustainable Infrastructure and Built Environment in Developing Countries, Bandung (Indonesia), November 2-3, Proceeding ISBN 978-979-98278-2-1, pp 20-25, 2009.

[3] Sun, D. D., Zhang, D. Lai : Stabilization of mercury using waste ladle furnace slag. Journal of the Air \& Waste Management Association. 63. 1469-1478, 2013.

[4] Romy. S. Edwin, M. De Schepper, E. Gruyaert, N. De Belie : Effect of secondary copper slag as cementitious material in ultra-high performance mortar, Construction and Building Materials. 119. 31-44, 2016.

[5] Sriyani, R. dan Ngii, E.: Perencanaan adukan beton dengan slag nikel sebagai agregat dan abu sekam padi sebagai bahan tambah. Jurnal Metropilar. Vol. 9 No. 3, Edisi Juli, 2011.

[6] Mustika, W., Salain, I. M. A. K., J. K. Sudarsana: Penggunaan Terak Nikel Sebagai Agregat Dalam Campuran Beton. Jurnal Spektran. The $5^{\text {th }}$ Environmental Technology and Management Conference "Green Technology towards Sustainable Environment", November 23 - 24, Bandung, Indonesia, 2015.

[7] Salain, I. M. A. K., Sudarsana, J. K., Wayan Mustika. : Mechanical Properties of Concrete Using Nickel Slag As Coarse Aggregate. Jurnal Spektran. Vol. 4, No. 2, pp. 3645, 2016.

[8] Kardiyono: Teknologi Beton, Edisi pertama, Biro Penerbit KMTS FT UGM, Yogyakarta, 2007. 